\title{
Effect of Integrated Nutrients Management and some Insecticides on Quality of Cowpea Plants (Vigna unguiculata L.) and Associated Sucking Insect Pests Hayam A. El-shaboury ${ }^{1}$ and Eftkhar E. Abohatab ${ }^{2}$ ${ }^{1}$ Soils, Water and Environment Res. Inst, Agric. Res. Centre, Giza, Egypt \\ ${ }^{2}$ Plant Protection. Res. Inst., Agric. Rec. Centre, Dokki, Giza, Egypt
}

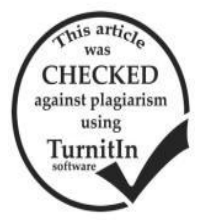

\section{ABSTRACT}

Two field experiments were conducted during the two summer seasons of 2017 and 2018 a special farm ,in El Mansoura , Dakahlia Governorate on the first week of May in a complete randomized block design to evaluate effect of Gaucho(G) systematic insecticides as seed coating before sowing against sucking pests which attack cowpea (Kaha -1 cultivar) during seedling period ( from emergence until 60 days old ) as compared with untreated seed (control) also, Gaucho spraying (Gs), K.Z.oil and integrated nutrients management (I.N.) $\mathrm{Fe}+\mathrm{Zn}+\mathrm{Mn}+\mathrm{Cu}$ rate of $0.3,0.3,0.3,0.15 \mathrm{gm} \mathrm{L}^{-1}$, respectively as EDTA chelated form with potassium sulphate soaked rate of $10 \mathrm{gm} \mathrm{L}^{-1}$, three times through growth stages on vegetative growth characters, Photosynthetic Pigments, Yield, Yield components and Chemical constituents, quality and sucking insect pests .It can be observed from the results that all parameters for both seasons were increased significantly compared with non-treated (control) of vegetative growth as indicated by plant height $(\mathrm{cm})$, no. of branches/plant, no. of leaves/plant. These effects were more obvious especially at the treatment of seed coating before sowing by Gaucho insecticide with Integrated nutrients management (G+I.N.) . Data revealed that addition of integrated nutrients with seed coating by Gaucho significantly increased chlorophyll a, b , a + b and carotene contents in cowpea leaves ,as well as, No. of pods plant ${ }^{-1}$, No. of seed $\operatorname{pod}^{-1}, 100$ seed weight (g), Crude protein, total carbohydrate and, green pod ,seed and straw yields (ton/fed) . Also, N, P and K contents $\left(\mathrm{kg} \mathrm{fed}^{-1}\right)$ in both green pods, seeds and straw increased significantly with these treatments. The results indicated also that , Aphids represented the most insect pest attacking cowpea with a ratio around $44 \%$ followed by thrips (24\%), While whitefly and leaf miner $(15 \%)$ each . Leafhopper represented the lower pest attack (2\%). From the present study, it can be concluded that Imidacloprid (Gaucho $70 \mathrm{WS}$ at $7 \mathrm{~g} / \mathrm{kg}$ seed) can be coating seed before sowing and using Integrated nutrients management are safe ,cheep, improve yield quality, protection plant form sucking pests and environmentally-friendly of cowpea . also, This information might be helpful to the vegetables growers.

Keywords: Cowpea plants ,micronutrients ,potassium sulphate, Gaucho, K.Z.Oil, , vegetative growth, sucking pests, yield, quality.

\section{INTRODUCTION}

Cowpea (Vigna unguiculata (L.) Walp) Family : Leguminosae) . It is an important grain legume in Africa, parts of the Americas and in Asia. The seeds can be consumed fresh along with the pods and leaves as a vegetable. Dried seeds are consumed after cooking. The plant can be used after harvest a silage FOR animal because it have adequate contents of protein, dietary fiber, carbohydrates, vitamins and phytochemicals (Devi et al., 2015), Also, cowpea one is the important vegetable crops in Egypt, especially with the high prices of animal protein. The total area under cultivation of this crop was estimated at 11523 fed. for dry seed in 2015 with a mean production of $1.124 \mathrm{ton} / \mathrm{fed}$. Also, the area that produced green pods was 6331 feddans with a mean of 3.947 ton/fed. (Dep.t, Agric , Statis. , Ministry of Agric., Giza, Egypt).

Seed represent a chief source of protein and carbohydrates content. Also, cowpea can grow easily in the new reclaimed lands (Abdel-Aziz and Salem, 2013 ). Plant nutrition play the most roll increase plant production. Nitrogen is one of the major elements for plants growth and development (Adelusi and Aileme, 2006).

New trends in crop protection are using the lowest rat of pesticidesto control of pests such as aphids, whiteflies, thrips and mites in horticultural crops currently requires an increased number of applications and application doses. Imidacloprid is a widely used insecticide with relatively low human toxicity. It is a systemic insecticide. spray oils are alternatives to synthetic pesticides for the control of some of these crop pests (Chauvel and Brustel, 1998 and Sieburth,et al., 1998). Mineral oils have recently been introduced among the recommended products for insect pest management (IPM) programmes.
The use of oils has Many advantages over conventional pesticides, as they are less disruptive to natural enemies, insects do not develop resistance to them, they are nontoxic to vertebrates and they break down easily in the environment, helping their use far more sustainable in the long term. ( Simons and Zitter,1980). Increase in the production of grain legumes therefore would offer a partial solution to the shortage of world protein supply. For this reason there has been increasing research effort to improve tolerant of plant seeds quality and yielding capacity of grain legumes such as cowpea .

Gaucho is a seed treatment product with excellent systemic properties acting through the roots, ensuring protection of the plant against pests from the time of sowing well into the growing period. It has a broad spectrum of activity, particularly against sucking pests . In the soil, the active ingredient is released from the seed and forms a treatment-halo around the seed. Gaucho is absorbed very efficiently by the germinating plant and is transported in the sap-flow to the stem and leaves. Gaucho fits very well in IPM-systems and the grower is minimally exposed. Seed treatment before plantation ( www. Egypt .cropscience.bayer.com).

plants require conditions of balanced nutrition Just like humans where proper plant nutrition is an important factor for improving yield, quality of agricultural productions and pest resistance .

Potassium has direct synergistic relationships with two micronutrients namely: iron and manganese. Manganese is very important component of photosynthesis. Also, Iron is constituent of peroxidase and catalase, which are defense enzymes of the plant. Zinc and copper also have indirect effects on potassium (Ujwalaranade,2011).

Deficiencies of micronutrients are more frequent in many soil types especially with increase soil $\mathrm{pH}$ over 7.5, 
the availability and uptake of micronutrients by plants decrease (Eisa and Ali, 2014).

Nutrient elements are needed in relatively small quantities for adequate plant growth and production, their deficiency may cause a great disturbance in the physiological and metabolic processes in the plant (Babaeian et al. 2011).

Zinc $(\mathrm{Zn})$ is essential in the largest number of proteins for their functions (i.e. protein synthesis) and its contribution to the structural integrity of a number of proteins (Hafeez et al.2013).

Copper $(\mathrm{Cu})$ is on essential plant nutrient required for chlorophyll synthesis ,respiration ,carbohydrate and protein metabolism (Marschner 1995).

This research aimed to evaluate the efficiency of Imidacloprid Gaucho systematic insecticides as seed coating before sowing against sucking pests which attacking cowpea during seedling period ( from emergence until 60 days old ) and compared with untreated seed (control).Also , if it can used as spraying , K.Z. oil and integrated nutrients management to protect plant from sucking pest, improve content of plant, and quality yielding of cowpea .

\section{MATERIALS AND METHODS}

Two field experiments were carried out during the two summer seasons of 2017 and 2018 at special farm in El Mansoura, Dakahlia Governorate, to evaluate effect of integrated nutrients management and some insecticides on quality of cowpea plants and sucking insect pests.

Some physical and chemical analyses of the experimental soils at the depth of 0-30 $\mathrm{cm}$ are shown in Table 1,as described by Page et al. (1982) and Klute (1986).

Table 1. Physical and chemical, properties of the experimental field during years 2017 and 2018 before planting .

\begin{tabular}{|c|c|c|c|c|c|c|c|c|c|c|}
\hline \multirow{2}{*}{ Season } & \multirow{2}{*}{$\begin{array}{c}\mathrm{CaCO}_{3} \\
(\%)\end{array}$} & \multirow{2}{*}{$\begin{array}{l}\text { O.M } \\
(\%)\end{array}$} & \multicolumn{5}{|c|}{ Particle size distribution (\%) } & \multirow{2}{*}{\multicolumn{3}{|c|}{$\begin{array}{l}\text { Texture } \\
\text { class }\end{array}$}} \\
\hline & & & Coarse sand & \multicolumn{2}{|c|}{ fine sand } & Silt & Clay & & & \\
\hline $1^{\text {st }}$ & 3.97 & 1.52 & 5.13 & \multicolumn{2}{|c|}{18.22} & 31.17 & 45.48 & \multicolumn{3}{|c|}{ clay } \\
\hline $2^{\text {nd }}$ & 3.68 & 1.50 & 5.16 & & & 31.15 & 45.95 & \multicolumn{3}{|c|}{ clay } \\
\hline \multirow{3}{*}{ Season } & \multirow{3}{*}{\multicolumn{2}{|c|}{$\begin{array}{c}\mathrm{pH}(1: 2.5) \text { Soil : Water } \\
\text { suspensoon }\end{array}$}} & \multirow{3}{*}{$\begin{array}{c}\mathrm{EC} \mathrm{dSm}^{-1} \text { ( Soil } \\
\text { paste Extract) }\end{array}$} & \multicolumn{7}{|c|}{ Available nutrients $\left(\mathrm{mg} \mathrm{kg}^{-1}\right)$} \\
\hline & & & & \multicolumn{3}{|c|}{ Macro } & \multicolumn{4}{|c|}{ Micro } \\
\hline & & & & $\mathrm{N}$ & $\mathrm{P}$ & $\mathrm{K}$ & $\mathrm{Fe}$ & $\mathrm{Mn}$ & $\mathrm{Zn}$ & $\mathrm{Cu}$ \\
\hline $1^{\text {st }}$ & 8.07 & & 1.76 & 3.6 & 6.75 & 185.2 & 2.66 & 1.29 & 0.94 & 0.46 \\
\hline \multirow[t]{2}{*}{$2^{\text {nd }}$} & 8.03 & & 1.74 & 9.7 & 6.49 & 183.6 & 2.60 & 1.25 & 0.90 & 0.44 \\
\hline & \multicolumn{10}{|c|}{ Soluble ions meq $\mathrm{L}^{-1}(1: 5$ soil : water extract $)$} \\
\hline \multirow[t]{2}{*}{ Season } & \multicolumn{5}{|c|}{ Cations } & \multicolumn{5}{|c|}{ Anions } \\
\hline & $\mathrm{Ca}^{++}$ & $\mathrm{Mg}^{++}$ & $\mathrm{Na}^{+}$ & & & $\mathrm{CO}_{3}^{-}$ & $\mathrm{HC}_{3}^{-}$ & & & $\mathrm{SO}_{4}^{-}$ \\
\hline $1^{\text {st }}$ & 3.92 & 2.29 & 4.47 & & & 0.00 & 2.13 & & & 5.37 \\
\hline $2^{\text {nd }}$ & 3.84 & 2.30 & 4.44 & & & 0.00 & 2.11 & & & 5.39 \\
\hline
\end{tabular}

The experiment was laid out in a complete randomized block design included five treatments with four replicates as the follows :

1- Control.

2 - Seed coating before sowing by Gaucho insecticide (Gaucho® WS 70 is a water dispersible containing $7 \mathrm{~g}$ $/ \mathrm{kg}$ imidaclopred ) with one spray after 60 days from sowing .

3-Integrated nutrients management of macronutrients recommended soil (NPK) and foliar spraying micronutrients $\mathrm{Fe}, \mathrm{Zn}, \mathrm{Mn}, \mathrm{Cu}$ with Potassium sulphate soaked at rate of $0.3,0.3,0.3,0.15 \mathrm{gm} \mathrm{L}^{-1}$ as EDTA chelated with potassium sulphate soaked (10 $\mathrm{gm} \mathrm{L}^{-1}$ ) .

4- Seed coating before sowing by Gaucho insecticide with Integrated nutrients management .

5- Seed coating before sowing by Gaucho insecticide and spraying mineral oil (K.Z.95\% 1.5L/fed.) after 60 days from sowing .

An area of about 1/4 feddan was prepared (5 treatments $\times 4$ rep.) and divided into 20 plots (each plot about $40 \mathrm{~m}, 5 * 8 \mathrm{~m}, 6$ ridges) separated by a border of $1 \mathrm{~m}$ path and $2 \mathrm{~m}$ between each replication in a complete randomized block design .

Pure seeds of cowpea (Kaha-1) were obtained from the Agricultural Research Center, Giza , Egypt were sown $(2$ seeds/hole) on two sides with shape leg of beard on ridge (widths of $75 \mathrm{~cm}$ with $4 \mathrm{~m}$ length spacing $20 \mathrm{~cm}$ between plants. The Bacterial strains microbial inoculated seeds were sown and covered by sand in a hill. Organic manure was used at $10 \mathrm{~m}^{3} \mathrm{fed}^{-1}$, spread and thoroughly mixed with the soil surface layer $(0-30 \mathrm{~cm})$ before seed sowing during the soil preparation .

The middle three ridges were possessed for seeds and straw yield, whereas the other ridges were used to measure plant growth characters and green pod yield .

The basic NPK fertilization was applied in the whole site as recommended .They were applied at rate of $45 \mathrm{~kg} \mathrm{~N} \mathrm{fed}^{-1}$ as ammonium sulfate $(20.5 \% \mathrm{~N}), 22.5 \mathrm{~kg}$ $\mathrm{P}_{2} \mathrm{O}_{5}$ fed $^{-1}$ as super phosphate $\left(15.5 \% \mathrm{P}_{2} \mathrm{O}_{5}\right)$ and $24 \mathrm{~kg} \mathrm{~K} \mathrm{~K}_{2} \mathrm{O}$ fed $^{-1}$ as potassium sulfate $\left(48 \% \mathrm{~K}_{2} \mathrm{O}\right)$. Phosphorus fertilizer was added to the soil during land preparation, while $\mathrm{N}$ and $\mathrm{K}$ fertilizers were applied in two doses; after one month and at flowering stage .

Micronutrients foliar were applied at rate of $0.3,0.3,0.3,0.15 \mathrm{gm} \mathrm{L}^{-1}$ as EDTA chelated with potassium sulphate soaked $10 \mathrm{gm} \mathrm{L}^{-1}$ (it kept for 48 hours) (Nassar et. al., 2005) three times during the vegetative, begining of the flowering and setting \& early pod formation growth 30,45 and 60 days from sowing .

\section{Entomological studies :}

Insecticides :

1/ (Gaucho 70\% W.S ) neonicotinoides as commercial formulation was tested in the present study chloronictonyl , Imidacloprid 1- [(6-chloro-3-pyridinl) methyl ] - N-nitro2-imidazolidinimine].

2/ K.Z. oilß (K.z.) 95\%E.C by 1.5 L/fed. (Mineral oil) Kafr El-Ziat Pesticides and Chemicals Co. 


\section{Samples :}

10 leaves were weekly picked randomly from each plot. Each plant was carefully examined at morning 6-8 o'clock at zero time and every week for a total Examined using a Binocular microscope and the total numbers of sucking pests per sample was recorded and tabulated .

\section{Plant data recorded:}

\section{a-Vegetative growth characters:}

Five plants were taken random from each plot at 70 days after sowing to evaluate the following vegetative characters .i.e., plant height $(\mathrm{cm})$, number of leaves /plant, number of branches/plant, dry weights of both green pods, seeds and straw (g/plant) .

b- Photosynthetic Pigments : Chlorophyll contents a, b, $(a+b)$ and carotene in the fresh recently expanded leaves (mg/g F.W) were determined colorimetrically as described by Sadasivam and Manickam, (1996).

Yield and its components :

Green pod yield was harvested at 75 days and both seed and straw yields were estimalated 90 days after sowing(ton/fed), No. of pods plant ${ }^{-1}$, No. of seed pod $^{-1}$, 100 seed weight $(\mathrm{g})$ were determined.

\section{d-Chemical constituents and quality :}

$\mathrm{N}, \mathrm{P}$ and $\mathrm{K}$ contents $\left(\mathrm{kg} \mathrm{fed}^{-1}\right)$ in both green pods, seeds and straw were deterimined in wet digested extract used the methods described by Chapman and Pratt (1961).

Total carbohydraties (\%) was deterimined as described by (Shumaila and Safdar,2009), Protein content (\%) was calculated by multiplying N\% x 6.25 (FAO, 2003).

Statistical analysis: For all recorded data, combined analyses of the two studied seasons were statistically analyzed according to Gomez and Gomez (1984). The least significant differences (L.S.D) test were used to compare the means of treatments at the $5 \%$ level of significance.

\section{RESULTS AND DISCUSSION}

\section{Photosynthetic pigments and vegetative growth characteristics :}

Table( 2), data indicated the effect of integrated nutrient management and some insecticides significantly increased photosynthetic pigments and plant growth as parameters plant height $(\mathrm{cm})$, no. of branches/plant, no. of leaves/plant, dry weights of both green pods, seeds and straw (g/plant).

Table 2. Effect of integrated nutrients management and some insecticides on photosynthetic pigments and some vegetative growth characteristics of cowpea plants*.

\begin{tabular}{|c|c|c|c|c|c|c|c|c|c|c|}
\hline \multirow[b]{2}{*}{ Treatments } & \multicolumn{4}{|c|}{ Photosynthetic Pigments (mg / g F. W) } & \multirow{2}{*}{$\begin{array}{c}\text { Plant } \\
\text { height } \\
\text { (cm) }\end{array}$} & \multirow{2}{*}{$\begin{array}{c}\text { No. } \\
\text { branches } \\
\text { /plant }\end{array}$} & \multirow{2}{*}{$\begin{array}{l}\text { No. of } \\
\text { leaves/ } \\
\text { plant }\end{array}$} & \multicolumn{3}{|c|}{ Dry weight (g/plant) } \\
\hline & Chl.(a) & Chl.(b) & Chl.(a+b) & carotene & & & & Green Pods & Seeds & Straw \\
\hline Control & 0.613 & 0.433 & 1.046 & 0.805 & 43.23 & 3.86 & 24.50 & 13.24 & 26.58 & 28.42 \\
\hline G+Gs & 0.640 & 0.454 & 1.094 & 0.832 & 46.23 & 4.23 & 30.34 & 14.08 & 29.85 & 30.98 \\
\hline I.N. & 0.654 & 0.467 & 1.121 & 0.847 & 48.72 & 4.58 & 33.01 & 15.15 & 35.24 & 33.76 \\
\hline G+I.N. & 0.681 & 0.489 & 1.170 & 0.875 & 52.60 & 4.95 & 38.70 & 15.65 & 38.39 & 36.24 \\
\hline G+K.Z oil & 0.627 & 0.445 & 1.072 & 0.819 & 45.18 & 4.11 & 28.14 & 13.74 & 28.42 & 29.55 \\
\hline L.S. $D_{0.05}$ & 0.004 & 0.005 & 0.006 & 0.005 & 0.75 & 0.25 & 1.90 & 0.26 & 0.40 & 0.36 \\
\hline
\end{tabular}

*Mean values of the two investigated seasons.

Statistical analyses of data in Table 2, revealed that addition of significantly Integrated nutrients with seed coating by Gaucho increased chlorophyll $\mathrm{a}, \mathrm{b}, \mathrm{a}+\mathrm{b}$ and carotene contents in cowpea leaves .

Fouda and Abd-ELhamied (2017) found that foliar application with $(\mathrm{Zn}+\mathrm{Fe})$ under $100 \%$ P-fertilization resulted the highest values of chlorophyll $a, b$ and $a+b$ contents in cowpea leaves .

Also the isSAME results agree with those obtained by Abd EL-Razek et al.(2012) on Faba Bean ,EL-Waraky and Knany (2014) and EL-Afif et al.(2016) on Cowpea.

EL-Gabiery,et.al.(2012) reported that applying systematic pesticides ie. Gaucho and Cruiser as seed coating significantly increased leaf chlorophyll a, b and total chlorophyll contents, leaf area / plant, total dry weight / plant at 60 and 75 days old in both seasons and plant height at harvest and number of fruiting branches / plant in one season only compared with the control (untreated seeds with Gaucho or Cruiser ).

In Table(2),refer that all treatments increased significantly of vegetative growth as indicated by plant height $(\mathrm{cm})$, no. of branches/plant, no. of leaves/plant and dry weights of both green pods, seeds and straw. These effects were more obvious especially of treatment seed coating before sowing by Gaucho insecticide with integrated nutrients management. The probable reasons might be the stimulating effect of phosphorus on plant processes as phosphorus is a major constituent of plant cell nucleus and growing root tips which helped in cell division and root elongation. $\mathrm{P}$ involved in photosynthesis which is directly related with production of root biomass of plant and caused vigorous growth of plants and extensive root system leading to increased growth parameters. These results agree with those of Meena et al., (2005), Deo and Khaldewal (2009), Dotaniya et al., (2014) and Balai et al., (2017).

The positive results of the added $\mathrm{N}$ effects could be related to the important role of nitrogen and its vital contribution to several biochemical processes in the plant, related to growth (Marschner, 1986) and to its role in assimilating the photosynthetic reaction. Furthermore, plants with high nitrogen contents had higher levels of indigenous auxin and high gibberellin activity (Rajagopal and Rao, 1974). The present results matched well with those obtained by Knany et al. (2002) and Masoud and ElWaraky (2012). This means that $30 \mathrm{~kg} \mathrm{P}_{2} \mathrm{O}_{5}$ fed. $^{-1}$ was the best phosphorus rate to the studied pea. $\mathrm{Cu}$ is also essential for various enzmatic reactions, help in utilization of $\mathrm{Fe}$ during chlorophyll synthesis and nitrogen fixation by legume (Seliga 1993). 
Foliar application supplies nutrients for plants faster compared with fertilizer application to soil. In addition, it might related to the effect of microelements in plant physiology; Fe which plays an important role in sundry vital processes in plant such as photosynthesis consequently affecting plant growth; $\mathrm{Zn}$ is important for $14 \mathrm{C}$ fixed in the primary photosynthetic process (Lincoln and Zeiger, 2002).

\section{Yield and its components :}

Data in Table 3, indicated that No. of pods plant ${ }^{-1}$ No. of seed pod $^{-1}, 100$ seed weight $(\mathrm{g})$ and green pods, seeds and straw yield (ton fed $^{-1}$ ) of cowpea plants were increased, as affected by addition of foliar spraying micronutrients $\mathrm{Fe}, \mathrm{Zn}, \mathrm{Mn}, \mathrm{Cu}$ with potassium comparing with the untreated plants. The yield and its component parameters were increased significantly in response to using integrated nutrients management.

Mali et al., (2003) referred that the increase in seed yield of pigeon pea because of manganese, zinc and iron addition could possibly be due to the enhanced synthesis of protein and carbohydrates and their transport to the site of seed formation.

These results are agreed with those of Nasri et. al.(2011) , Salih (2013) and Balai et al., (2017). Also, Mekkei (2014) said that spraying $\mathrm{Fe}+\mathrm{Mn}+\mathrm{Zn}$ mixture produced the greatest number of pods plant $^{-1}$, number of seeds pod $^{-1}, 100$-seed weight, green pods yield, seed yield , straw yield and protein content maximum grain yield over control.

El-Waraky and Knany (2014) found that micronutrients with potassium spraying using $\mathrm{Fe}+\mathrm{Zn}+\mathrm{Mn}$ treatment was the most effective on yield and its components .Regarding the quality parameters, data at the same Table showed the significante effect of foliar application of micronutrients $\mathrm{Fe}, \mathrm{Zn}, \mathrm{Mn}, \mathrm{Cu}$ with potassium in comparison with untreated plants on $\mathrm{C}$. protein and T. carbohydrates.

Table 3. Effect of integrated nutrient management and some insecticides on yield, its components and quality*.

\begin{tabular}{|c|c|c|c|c|c|c|c|c|c|c|}
\hline \multirow{2}{*}{ Treatments } & \multirow{2}{*}{$\begin{array}{c}\text { No of pods } \\
\text { plant }^{-1}\end{array}$} & \multirow{2}{*}{$\begin{array}{l}\text { No of seeds } \\
\text { pod }^{-1}\end{array}$} & \multirow{2}{*}{$\begin{array}{c}100 \text { seed } \\
\text { weight }(\mathrm{g})\end{array}$} & \multicolumn{2}{|c|}{ Protein (\%) } & \multicolumn{2}{|c|}{ Total Carbohydrates (\%) } & \multicolumn{3}{|c|}{ Yield ( ton fed ${ }^{-1)}$} \\
\hline & & & & Green Pods & Seeds & Green Pods & Seeds & Green Pods & Seeds & Straw \\
\hline Control & 22.8 & 10.3 & 12.27 & 17.09 & 19.02 & 58.13 & 62.54 & 2.46 & 1.15 & 4.78 \\
\hline G+Gs & 24.2 & 10.7 & 12.52 & 19.31 & 21.31 & 58.83 & 63.37 & 2.75 & 1.30 & 5.12 \\
\hline I.N. & 27.4 & 11.1 & 13.14 & 20.54 & 22.74 & 59.24 & 63.75 & 3.14 & 1.52 & 5.49 \\
\hline G+I.N. & 29.0 & 11.4 & 13.54 & 21.63 & 24.13 & 59.63 & 64.24 & 3.40 & 1.67 & 5.82 \\
\hline G+K.Z oil & 23.7 & 10.5 & 12.38 & 18.19 & 20.27 & 58.47 & 62.98 & 2.63 & 1.23 & 5.00 \\
\hline L. S. $D_{0.05}$ & 0.51 & 0.21 & 0.07 & 0.51 & 0.17 & 0.60 & 0.21 & 0.05 & 0.03 & 0.05 \\
\hline
\end{tabular}

*Mean values of the two investigated seasons.

Green pods and seeds protein content increased gradually with all treatments in both seasons. It worth to note that seed coating by Gaucho and foliar spraying micronutrients $\mathrm{Fe}, \mathrm{Zn}, \mathrm{Mn}, \mathrm{Cu}$ with potassium treatment surpassed other treatments in green pods and seeds protein content(21.63 and $24.13 \%$, respectively). However, the lowest protein content (17.09 and19.02\%, respectively) was obtained with control treatment in both seasons.

It is clear from the presented data (Table 3) that treating cowpea plants with P-fertilization as soil addition significantly affected C. protein and T.carbohydrates. Parameters increased with increasing P-fertilization, which recorded the highest values with foliar application micronutrients $\mathrm{Fe}, \mathrm{Zn}, \mathrm{Mn}, \mathrm{Cu}$ with potassium. It could be related to increasing in nodulation then increasing content of $\mathrm{N}$ or protein in legumes as a result of phosphorous fertilization. Magani and Kochinda (2009) reported that crude protein content of cowpea seed was increased significantly with increased rate of $\mathrm{P}(0,37.5$, and $75 \mathrm{~kg} \mathrm{ha}^{-1}$ )

Chavan et al. (2012) stated that great values of maximum protein content in cowpea grains reported as a result of application $40 \mathrm{~kg} \mathrm{ha}^{-1}$ zinc over $20 \mathrm{~kg} \mathrm{ha}^{-1}$ zinc. Applied zinc to crops were more powerful than others and had a huge growth because zinc had a vital part in stabilizing DNA and RNA structure, and involves in biosynthesis of growth promoting hormones such like gibberellins and IAA. Yadav et al., (2002); Mousavi (2011) and Pingoliya et al., (2014) reported that with the application of $30 \mathrm{~kg} \mathrm{P}_{2} \mathrm{O}_{5} \mathrm{ha}^{-1}$ and $4 \mathrm{~kg} \mathrm{Fe} \mathrm{ha}{ }^{-1}$, the protein content in seeds increased significantly comparing with their lower levels in mung bean.
It worthy to mention that supplies of micronutrients $(\mathrm{Fe}+\mathrm{Zn}+\mathrm{Mn})$ was superior also in yield attributes. This may be due to their positive effects on assimilates translocation, activation of photosynthetic enzymes , chlorophyll formation and improvement of plant growth (Farag et al. 2014).

\section{$N, P$ and $K$ contents in plant:}

Data in Table 4, indicated that the contents of $\mathrm{N}, \mathrm{P}, \mathrm{K}$ in both green pods, seeds and straw as affected by integrated nutrient management and some insecticides increased significantly in both green pods, seeds and straw . The highest content of nitrogen in both green pod, seed and straw at seeds coating by Gaucho with Integrated nutrients, but the lowest content of nitrogen at control . Also, the results show that the highest content of phosphorus and potassium at seeds coating by Gaucho with integrated nutrients treatment compared with treatment of control. These results are in harmony with those obtained by El-Azab (2016)who found that the application of NPK with micronutrients sparing to leaves increased of N,P,K concentration and its uptake.

Table 4. Contents of $\mathrm{N}, \mathrm{P}, \mathrm{K}$ (Kg/fed) in both green pods, seeds and straw as affected by integrated nutrient management and some insecticides*.

\begin{tabular}{|c|c|c|c|c|c|c|c|c|c|}
\hline \multirow{2}{*}{ Treatments } & \multicolumn{3}{|c|}{ Green Pods } & \multicolumn{3}{|c|}{ Seeds } & \multicolumn{3}{|c|}{ Straw } \\
\hline & $\mathbf{N}$ & $\mathbf{P}$ & $\mathbf{K}$ & $\mathbf{N}$ & $\mathbf{P}$ & $\mathbf{K}$ & $\mathbf{N}$ & $\mathbf{P}$ & $\mathbf{K}$ \\
\hline Control & 8.19 & 0.486 & 6.96 & 18.39 & 1.14 & 17.13 & 6.64 & 0.561 & 7.42 \\
\hline $\mathrm{G}+\mathrm{Gs}$ & 9.86 & 0.612 & 8.20 & 23.09 & 1.52 & 21.26 & 9.56 & 0.766 & 9.35 \\
\hline I.N. & 11.28 & 0.722 & 9.25 & 29.00 & 1.91 & 26.13 & 11.80 & 0.927 & 10.88 \\
\hline G+I.N. & 12.25 & 0.792 & 10.08 & 33.71 & 2.24 & 29.79 & 14.14 & 1.085 & 12.33 \\
\hline $\mathrm{G}+\mathrm{K} . \mathrm{Z}$ oil & 9.11 & 0.552 & 7.68 & 20.83 & 1.33 & 19.16 & 8.11 & 0.657 & 8.31 \\
\hline L. S. $D_{0.05}$ & 0.25 & 0.036 & 0.26 & 0.51 & 0.14 & 0.44 & 0.56 & 0.045 & 0.48 \\
\hline
\end{tabular}


Foliar application of zinc increased pigeon pea and soybean seed yield respectively. Moreover, concentrations of $\mathrm{Zn}, \mathrm{Fe}, \mathrm{P}$ and $\mathrm{K}$ increased in the plant leaves with increasing zinc concentration in foliar spray solution (Osman et. al., 2000; Masood and Mishra 2001 and Nasri and Khalatbari 2011).

Verónica Estrada-Domínguez et al. (2018) reported that the highest contents of nitrogen, crude protein, phosphorus, potassium, calcium, iron, manganese and copper were obtained with the doses of 7 and $14 \mathrm{mM} \mathrm{L}^{-1}$ of Zn-EDTA in seeds of cowpea beans.

This result may be due to sharing of foliar micronutrients such as iron, zinc and manganese, which iron helped in the formation of chlorophyll, $\mathrm{Zn}$ has essential element and plays a role in plant enzymes, which contain in a functional structural or many enzymes or regulatory co-factor and for photosynthesis, protein synthesis, the synthesis of auxin, sexual fertilization and cell division. Also, zinc plays a special role in synthesizing proteins, DNA and RNA. It has been discovered that iron is activator of a lot of enzymes and it assume vital part in plant growth and production, including chlorophyll synthesis, chloroplast development and protein synthesis (Pingoliya et al., 2014 and El-Azab. 2016).

\section{Entomogcal studies:}

Generally, as shown in Table 5 , No real differences were noticed or recorded for the distribution of main scuking insect pests attacking on cowpea plants during the two successive seasons of this study. Aphid represented the most dominant insect pest attacking cowpea with a ratio around $44 \%$ followed by thrips (24\%), While whitefly and leaf miner (15\%) each . Leafhopper recorded the lower dominant insect pest attack $(2 \%)$ in this respect.
Table 5. The total number of collected sucking insect pests on cowpea all over the seasons and their occurrence percentages on cowpea plants during two successive seasons in summer 2017 and 2018 .

\begin{tabular}{|c|c|c|c|c|}
\hline \multirow{2}{*}{$\begin{array}{l}\text { The main } \\
\text { sucking pests }\end{array}$} & \multicolumn{2}{|c|}{2017} & \multicolumn{2}{|c|}{2018} \\
\hline & $\begin{array}{c}\text { Total } \\
\text { number }\end{array}$ & $\begin{array}{c}\text { Occurrence } \\
\%\end{array}$ & $\begin{array}{c}\text { Total } \\
\text { number }\end{array}$ & $\begin{array}{c}\text { Occurrence } \\
\% \\
\end{array}$ \\
\hline $\begin{array}{l}\text { Aphids The } \\
\text { A. gossypii }\end{array}$ & 3893 & 43.7 & 3796 & 43.9 \\
\hline Trips tabaci & 2104 & 23.6 & 2031 & 23.5 \\
\hline $\begin{array}{l}\text { The whitefly } \\
\text { B. tabaci }\end{array}$ & 1363 & 15.3 & 1341 & 15.6 \\
\hline $\begin{array}{l}\text { The serpentine } \\
\text { leaf miner } \\
\text { L. trifolii }\end{array}$ & 1339 & 15.1 & 1268 & 14.7 \\
\hline $\begin{array}{l}\text { leafhopper } \\
\text { Emposca. spp }\end{array}$ & 200 & 2.3 & 198 & 2.3 \\
\hline Total & 8899 & $100 \%$ & 8634 & $100 \%$ \\
\hline
\end{tabular}

Results of the experiment for two seasons conducted to evaluate the tolerance of cowpea against Aphids, thrips spp, the whitefly, the serpentine leaf miner and the leaf hopper are presented in the Table(6) showed that, Overall mean of all insects of observation revealed that ,population of aphids on different treatments ranged between( 52.8 aphids/10 leaves) control to( 9.75 aphids/10 leaves). (G+Gs) recorded least aphid population and found to be significantly superior over all teratment. Mean thrips population revealed $(\mathrm{G}+\mathrm{I} . \mathrm{N})$ that had lowest number of thrips(7.64thrips/10 leaves) .( G+K.Z. OIL) recorded least the serpentine leaf mine L. trifolii 1.45 a \pm 3.21 mean while leafhopper was the lowest density. and no significantly beteween all teratment.

Table 6. Average numbers of some sucking insect pests on cowpea per 10 leaves with different treatment during summer seasons 2017 and 2018*.

\begin{tabular}{lcccccccccc}
\hline insects & \multicolumn{2}{c}{$\begin{array}{c}\text { The aphids } \\
\text { A. } \text { gossypii }\end{array}$} & \multicolumn{2}{c}{ Thrips spp. } & \multicolumn{2}{c}{$\begin{array}{c}\text { The whitefly } \\
\text { B. tabaci }\end{array}$} & $\begin{array}{c}\text { The serpentine leaf miner } \\
\text { L. trifolii }\end{array}$ & $\begin{array}{c}\text { leafhopper } \\
\text { Emposca s pp }\end{array}$ \\
& 2017 & 2018 & 2017 & 2018 & 2017 & 2018 & 2017 & 2018 & 2017 & 2018 \\
treatment & $52.08 \mathrm{a}$ & $51.08 \mathrm{a}$ & $13.00 \mathrm{a}$ & $12.00 \mathrm{a}$ & $12.92 \mathrm{a}$ & $12.90 \mathrm{a}$ & $11.17 \mathrm{a}$ & $9.20 \mathrm{a}$ & $1.58 \mathrm{a}$ & $1.54 \mathrm{a}$ \\
Control & \pm 61.89 & \pm 51.88 & \pm 25.88 & \pm 24.38 & \pm 13.72 & \pm 12.44 & \pm 24.98 & \pm 21.48 & \pm 1.16 & \pm 1.12 \\
& $9.75 \mathrm{bc}$ & $10.70 \mathrm{bc}$ & $12.08 \mathrm{a}$ & $11.17 \mathrm{a}$ & $5.25 \mathrm{a}$ & $4.86 \mathrm{a}$ & $1.92 \mathrm{a}$ & $1.81 \mathrm{a}$ & $1.25 \mathrm{a}$ & $1.20 \mathrm{a}$ \\
\multirow{2}{*}{${ }_{+} \mathrm{G}_{\mathrm{S}}$} & \pm 6.34 & \pm 4.34 & \pm 11.33 & \pm 10.12 & \pm 4.11 & \pm 4.60 & \pm 3.27 & \pm 2.13 & \pm 2.38 & \pm 2.33 \\
& $34.42 \mathrm{abc}$ & $32.12 \mathrm{abc}$ & $19.17 \mathrm{a}$ & $16.20 \mathrm{a}$ & $10.00 \mathrm{a}$ & $10.22 \mathrm{a}$ & $7.83 \mathrm{a}$ & $6.13 \mathrm{a}$ & $1.42 \mathrm{a}$ & $1.39 \mathrm{a}$ \\
I.N. & \pm 26.31 & \pm 27.20 & \pm 17.38 & \pm 15.23 & \pm 7.85 & \pm 8.00 & \pm 15.35 & \pm 14.35 & \pm 1.24 & \pm 1.26 \\
& $28.33 \mathrm{abc}$ & $27.33 \mathrm{abc}$ & $8.75 \mathrm{a}$ & $7.64 \mathrm{a}$ & $9.17 \mathrm{a}$ & $9.11 \mathrm{a}$ & $6.42 \mathrm{a}$ & $6.92 \mathrm{a}$ & $1.58 \mathrm{a}$ & $1.51 \mathrm{a}$ \\
G +I.N. & \pm 27.50 & \pm 25.420 & \pm 8.51 & \pm 7.41 & \pm 6.58 & \pm 5.81 & \pm 15.96 & \pm 13.23 & \pm 1.51 & \pm 1.41 \\
& $23.00 \mathrm{bc}$ & $21.00 \mathrm{bc}$ & $17.42 \mathrm{a}$ & $16.34 \mathrm{a}$ & $9.50 \mathrm{a}$ & $8.50 \mathrm{a}$ & $1.75 \mathrm{a}$ & $1.45 \mathrm{a}$ & $1.83 \mathrm{a}$ & $1.82 \mathrm{a}$ \\
G+K.Z. oil & \pm 21.04 & \pm 22.15 & \pm 18.69 & \pm 18.69 & \pm 11.26 & \pm 10.22 & \pm 3.81 & \pm 3.21 & \pm 1.99 & \pm 1.85 \\
\hline LSD .5 & 24.78 & 23.81 & 15.8 & 14.6 & 22.00 & 21.22 & 14.26 & 13.10 & 1.30 & 1.25 \\
\hline
\end{tabular}

*Means followed by a common letter are not significantly different at the $5 \%$ level Duncan's Multiple Range Test.

The obtained results showed that a positive effect of a neonicotinoid insecticide, imidacloprid, as seed treatment combined with Integrated nutrients managemen, oil applications and foliar spraying by Gaucho during the vegetative season. In seed vegatables crops, imidacloprid is commonly used as a systemic treatment to protect plants against scuking insects.

Aphids which were one of the most important insect pests of cowpea preferred to colonize prostrate varieties to erect ones in growth habit.

This type of data varied from season to season because the incidence and severity of insect attack was not constant. Other causes of flower and pod losses occurred due to also variable environmental factors.

Don Huber.et.al (2012) furthermore studied the visual factors such as colour of leaves are important for recognition or orientation. For example,noitcid many aphid species tend to settle on yellow-reflecting surfaces common with nutrient deficiency .depend on visual factors such as colour of leaves are important for recognition or orientation

EL- Gabiery, et al(2012) studied the insecticidal activity of two neonicotinoides as seed treatment at two rates against sucking pests Thrips tabaci (Lind.) and Aphis 
gosspii (Glover).Data indicated that the descending order of protective efficiency according to mean number of $\%$ reduction or the peak of activity of this insect were as follows: Gaucho with two rates, high rate of Cruiser and then the low rate of Cruiser. Therefore, choosing will be according to economical consideration. i.e. availability of product and unit price. On the other hand, the physiological and botanical aspects differentiated between the rate of use of these products as follows , Gaucho $5 \mathrm{~g} / \mathrm{kg}$ seeds had positive effect and Cruiser with $2 \mathrm{~g} / \mathrm{kg}$ seeds was better in this respect.

Begoñ a Mart'in-Lo' pez et al.,(2006) tested 4 oils were a horticultural mineral oils, essintial oil of rapeseed, essintial oil of soya and a raw fish oil. After the oils were sprayed alone on pepper plants infested with $m$. persicae, mineral oil caused the highest mortality of aphids (over $80 \%$ ). However, sprayed on aphid-infested pepper plants, the mortality rates achieved by Imidacloprid/mineral oil and Iimidacloprid/rapeseed oil mixtures were significantly higher than those achieved by imidacloprid . The oils applied as $10 \mathrm{ml}$ litre-1 emulsions in water did not cause symptoms of phytotoxicity on the potato plants, and yield was not reduced.

Mazen Khaddam and Saleem Raia (2012) studied the effect of treating seed before planting with Imidacloprid insecticide $(0.5,1, \quad 1.5 \mathrm{~g}$ Imidacloprid $/ 5 \mathrm{~g}$ seeds) and spraying mineral oil (Biolid) to reduce potato $\mathrm{Y}$ virus incidence and effect on the productivity of tobacco. Results showed a significant difference in virus spread between treatments in comparison with control treatment, and Imidacloprid, 1.5 gram without mineral oil was better on two tobacco varieties in three times. It reduced infection by $80.3,36.1,29.7 \%$ and $34.6,23.6,17.1 \%$ in 2010 growing season and 34.6, 23.6, $17.1 \%$ and 54.4, 36.5, $32.3 \%$ in 2011 growing season. Better treatment significantly increased the yield (fresh, dry) during the 2010 growing season which led to $83.1,104.3 \%$ and 65.4, $82 \%$ and during the 2011 growing season led to 58.4, $31.6 \%$ inVirgenia comparison with spraying mineral oil every week Burley50.8, 43.5\%comparison with control treatment.

Muhammad H. B. and M. Afzal (2002) studied the efficacy of four different insecticides viz., Imicon (imidacloprid) 25 WP @ 200 gm/acre. Pride (buprofezin) 25 WP ((I) 600 gm/acre. Digital (fenpropathrin) 20 EC @ 250 rnl/acre and Taophos (quinalphos) 25 EC @ 250 $\mathrm{ml} / \mathrm{acre}$, was tested against whitefly, Bemisia tabaci (Genn.) and Black thrips, Caliothrips indicus on Mung bean. Vigna radiata (L.), All the insecticides; tested, were found to be effective against whitefly and some were effective against black thrips. On numerical basis. however, a spray of Irnicon 25 WP @ 200 gm/acre was found to be most effective both for whitetly and black thrips.

\section{CONCLUSION}

From the present study This study indicated that, it can be concluded that Imidacloprid (Gaucho $70 \mathrm{WS}$ at 7 $\mathrm{g} / \mathrm{kg}$ seed) can be coating seed before sowing and using Integrated nutrients management (macronutrients recommended soil (NPK) and foliar spraying micronutrients $\mathrm{Fe}, \mathrm{Zn}, \mathrm{Mn}, \mathrm{Cu}$ with potassium sulphate soaked at rate of $0.3,0.3,0.3,0.15 \mathrm{gm} \mathrm{L}^{-1}$ as EDTA chelated with potassium sulphate soaked $10 \mathrm{gm} \mathrm{L}^{-1}$ ) are safe ,cheep ,improve yield quality , protection plant form sucking pests and environmentally-friendly of cowpea . Also, this information might be helpful to the vegetables growers.

\section{REFERENCES}

Abd El-Aziz, M. A. and M. F. salem (2013).Effect of microbial inocula tion on reduction of cowpea (vigna unguiculata, 1. walp) chemical fertilizers under newly reclaimed soils condition in Egypt. J. Plant Production, Mansoura Univ.,4(5):745-761.

Abd El-Razek, U.A.; E.A. Dorgham and S.M. Morsy (2012). Effect of certain micronutrients on some agronomic characters, chemical constituents and Alternairia leaf spot disease of faba bean. J. Plant Production, Mansoura Univ., 3 (11): 2699 - 2710.

Adelusi, A. A. and J. D. Aileme (2006). Effects of light and nutrient stress on some growth parameters of cowpea (Vigna unguiculata I. Walp). Res. J. Bot., 1:95-103.

Babaeian, M.; A. Tavassoli, A. Ghanbari, Y. Esmaeilian and M. Fahimifard (2011). Effects of foliar micronutrient application on osmotic adjustments, grain yield and yield components in sunflower (Alstar cultivar) under water stress at three stages. Afr. J. Agric. Res., 6 (5): 1204- 1208.

Balai, K.; Y. Sharma, M. Jajoria, P. Deewan and R. Verma (2017). Effect of Phosphorus, and Zinc on Growth, Yield and Economics of Chickpea (Cicer aritinum L.). Int. J. Curr. Microbiol. App. Sci., 6 (3): 11741181.

Begoñ a Mart'in-Lo' pez, Ianire Varela, Silvia Marnotes and Cristina Cabaleiro(2006) Use of oils combined with low doses of insecticide for the control of Myzus persicae and PVY epidemics Pest Manag Sci 62:372-378.

Chapman, D. H. and P. E. pratt (1961). "Methods of Analysis for Soil, Plant and Waters". Univ. of Calif., Div. Agric. Science, USA.

Chauvel, G. and M. Brustel (1998). Use of oils against mites, aphids and scales in green area. PHM Rev Hort 389:44-49.

Chavan, A. S.; M. R. Khafi, A. D. Raj and R. M. Parmar (2012). Effect of potassium and zinc on yield, protein content and uptake of micronutrients on cowpea (Vigna unguiculata (L.) walp). Agric. Sci., Digest, 32, 175-177.

Deo, C. and R. B. Khaldelwal (2009). Effect of P and S nutrition on yield and quality of chickpea (Cicer arietinum L.) J. I. Soc. Soil Sci., 57(3): 352-356.

Devi, C. B.; A. Kushwaha,. and A. Kumar (2015). Sprouting characteristics and associated changes in nutritional composition of cowpea (Vigna unguiculata). Ind. J. Food Sci. Technol. 52(10):6821-6827.

Don Huber,Volker Römheld and Markus Weinmann(2012) "Relationship between Nutrition, Plant Diseases and Pests" . (C) Elsevier Ltd. All rights reserved. 295 chaptar 10. 
Dotaniya, M. L.; K. K. Pingoliya, M. Lata, R. Verma, K. L. Regar, P. Deewan and C. K. Dotaniya (2014). Role of phosphorus in chickpea (Cicer arietinum L.) production. African J. Agri. Res., 9 (15): 37363743.

Eisa, G. S. A. and T. B. Ali (2014). Impact spraying of some microelements on growth, yield, nitrogenase activity and anatomical features of cowpea plants. World J. Agric. Sci., 10 (2): 57-67.

EL-Afifi, S.T. ; M. M. Zaghloul, W. A. EL-Saady and R. E. EL-Gammal (2016). Effect of different levels of NPK fertilizers with the foliar application of iron, zinc and boron on vegetative growth and yield of cowpea. J. Plant Production, Mansoura Univ., Vol. 7(12): $1245-1254$.

El-Azab, M. E. (2016). Effects of Foliar NPK Spraying with Micronutrients on Yield and Quality of Cowpea Plants. Asian J. Applied Sci., 4 (2), 526533.

EL-Gabiery, A. E. ; E. A. Wahba and E. G. I. Hamada (2012). Response of cotton plant to seed coating with gaucho or cruiser and the efficiency of these treatments on sucking pests population. J. Plant Production, Mansoura Univ., Vol. 3 (10): 2495 2512.

El-Waraky,Y.B. and R.E. Knany (2014). Effect of inoculation with rhizobia, potassium and some micronutrients spraying on growth, seed yield and quality of cowpea. J. Agric. Res.Kafer El-Sheikh Univ. 40 (1):212-234.

FAO. Food energy - methods of analysis and conversion factors (2003). FAO food and nutrition paper 77. Report of a Technical Workshop, Rome, 3-6 December 2002.

Farag, I. A.A.; N.E. Eliwa, and A.A. H. El Khawaga (2014).Importance of gamma irradiation, micronutrient mixtures and their application methods for impeoving fab bean (Vicia faba L.) growth and yield. IOSR J. of Agric. and Veterinary Scie., Vol.7 (7) : 48-57.

Fouda, K. F. and A. S. Abd-Elhamied (2017). Integrated Effect of Foliar Fertilization of Fe, Zn and Rates of $P$ Fertilization on Growth and Yield of Cowpea. J.Soil Sci. and Agric. Eng., Mansoura Univ., 8 (12): $733-740$

Gomez, K. A. and Gomez, A. A. (1984). "Statistical Procedures for Agricultural Research". John Wiley and Sons, Inc., New York.pp:680.

Hafeez, B.; Y.M. Khanif and M. Saleem (2013). Role of Zinc in Plant Nutrition- A Review Amer. J. Exper. Agric. 3(2): 374-391.

https://www.egypt.cropscience.bayer.com/Products/SeedTreatment/Gaucho.asp

Klute, A. (1986) Methods of Soil Analysis. Part-1: Physical and Mineralogical Methods (2nd) American Society of Agronomy, Madison, Wisconsin. U.S.A.

Knany, R.E. ; A.M. Masoud and M.H. Kasem (2002). Response of new cowpea cultivars to the nitrogen fertilizer sources and rates. $2^{\text {nd }}$ Inter.Conf. Hort.Sci.,10-12 Sept. Kafr EL-Sheikh, Tanta Univ., Egypt : 613-624.
Lincoln, T. and E. Zeiger (2002)" Plant Physiology", Publisher, Sinauer Associates; 3 edition. Pb.690.

Magani, I. E. and C. Kuchinda (2009). Effect of phosphorus fertilizer on growth, yield and crude protein content of cowpea (Vigna unguiculata [L.] Walp) in Nigeria. J. Applied Biosciences, 23: 1387 $-1393$.

Mali, G. C.; N. N.Sharma, H. K. Acharya, S. K. Gupta and P. K. Gupta (2003) Response of pigeon pea to $S$ and $\mathrm{Zn}$ fertilization on Vertisols in south-eastern plain of Rajasthan. Advances in Arid Legumes Research, pp. 267-271. Indian Arid Legumes Society, Scientific Publishers (India), Jodhpur.

Marschner, H. (1986)." Mineral Nutritional in Higher Plants". Academic Press, Harcourt Brace, Jovanovish Publisher, p.674.

Marshner, H(1995). "Mineral Nutrition of Higher Plants". $2^{\text {nd }}$ ed.Academic Press,London,pp889.

Masood, A. and J. P. Mishra ( 2001). Effect of foliar nutrition of boron and molybdenum on chickpea. Indian, J. Pulses Res.14 (1):41-43.

Masoud, A.M. and Y.B. EL-Waraky (2012).Effect of plant population and nitrogen fertilizer levels on seed yield and its components of some different cowpea genotypes .Alex. J.Agric.Res.,57(3):221-230.

Mazen, Kh. and S. Raia (2012) The Effect of Imidacloprid and mineral oil on reducing Potato $\mathrm{Y}$ virus on Tobacco varieties Burley and Virgenia. Tishreen Uninversity Journal for Research and Scientific studies - Biological Sciences Series, 34 (4):127145 .

Meena, K. N.; R. G. Pareek and R. S. Jat (2005). Effect of phosphorus and bio-fertilizers on yield and quality of chickpea. An. Agric. Res. New Series,22(3): 388-390.

Mekkei, M. E. R.(2014 ).Effect of micronutrients foliar application on productivity and quality of some faba bean cultivars (Vicia faba L.) . J. Plant Production, Mansoura Univ., Vol. 5 (8): 1391 1401.

Mousavi, S. R. (2011). Zinc in crop production and interaction with phosphorus. Australian J. Basic and Applied Sci., 5: 1503-1509.

Muhammad, H. B. and M. Afzal( 2002). Relative toxicity of different insecticides against whitefly Bemisia tabaci (Genn.) and black thrips Calithrips indicus on NM-92 mung bean, Vigna radiata .

Nasri, M. and M. Khalatbari (2011). Effect of different nitrogen, potassium and zinc fertilizer on quantities and qualities characteristic of green beans. Ecophysiol. Crop J. 3(1):82-93.

Nasri, M.; M. Khalatbari and H. A. Farahani (2011). Znfoliar Application Influence on Quality and Quantity Features in Phaseolous Vulgaris under Different Levels of $\mathrm{N}$ and $\mathrm{K}$ Fertilizers. $A d v$. Environ. Biol., (Adv. Environ. Biol.) 5 (5), 839846. Available online at: http://www.aensionline. com/aeb/2011/839-846.pdf 
Nassar, K.E.M.; Sh.M. Abd EL-Rasoul and G.M. ELShebiny (2005). Effect of foliar spraying with phosphorus and potassium on faba bean plant under calcareous soil conditions. Minufiya j.Agric. Res. 30(5):1625-1637.

Osman, A. S.; Y.M.Y. Abido and S.M.M. Allam (2000). Response of soybean to phosphorus and zinc fertilizer under irrigation regime. Ann. Agric. Sci. 45(1): 229-238.

Page, A. L.; R.H. Miller and D.R. Keeney (1982) Methods of Soil Analysis. Part-2: Chemical and Microbiological Properties. (2nd ed.) American Society of Agronomy, Madison, Wisconsin. USA.

Pingoliya, K. K.; M. L. Dotaniya and M. Lata (2014). Effect of iron on yield, quality and nutrient uptake of chickpea (Cicer arietinum L.). African J. Agric. Res., 9 (37), 2841-2845.

Rajagopal, V. and I.M. Rao (1974). Changes in the endogenous level of auxin and gibberellins like substance in the shoot apices of $\mathrm{N}$ deficient tomato plants. Aust. J. of Botany. 22: 429 - 435.

Sadasivam, S. and A. Manickam (1996). Biochemical Methods, $2^{\text {nd }}$ Ed. New Age international India.

Salih, H. M. (2013). Effect of Foliar Fertilization of Fe, B and $\mathrm{Zn}$ on nutrient concentration and seed protein of Cowpea "Vigna Unguiculata". IOSR J. Agric. and Veterinary Sci., 6 (3), 42-46. www.iosrjournals. Org

Seliga, H.(1993). The role of copper in nitrogen fixation in Lupinus luteus L.Plant and SoiL 155:349-352.
Shumaila, G. and M. Safdar (2009) Proximate Composition and Mineral Analysis of Cinnamon. Pakistan J. of Nutrition; 8 (9), 1456-1460. http:// dx.doi.org/10.3923/pjn.2009.1456.1460.

Sieburth, P.J.; W.J. Schroeder and R.T. Mayer (1998) Effects of oil and oil surfactant combination on silverleaf whitefly nymphs (Homoptera: Aleyrodidae) on collars. Fla Entomol81:446-450 .

Simons, J.N. and T.A. Zitter (1980). Use of oils to control aphid-borne viruses. Plant Dis 64:542-546.

Ujwalaranade, M. (2011). Interaction of micronutrients with major nutrients with special reference to potassium. Karnataka J. Agric. Sci.,24 (1) : 106109.

Verónica Estrada-Domínguez, César Márquez-Quiroz, Efraín la Cruz-Lázaro, Rodolfo Osorio-Osorio and Esteban Sánchez-Chávez (2018). Biofortification of cowpea beans (Vigna unguiculata L. Walp) with zinc: effect on yield and mineral content. Revista Mexicana de Ciencias Agrícolas special volume No.20.

Yadav, P. S.; P. R. Kameriya and S. Rathore (2002).Effect of phosphorus and iron fertilization on yield, protein content and nutrient uptake in mung bean on loamy sand soil. J. Indian Soc.Soil Sci., 50: 225226.

\section{تأثير التغذية المتوازنة ويعض المبيدات الحشرية على انتاجية اللوبيا والافات الحشرية الماصة المرتبطة بها

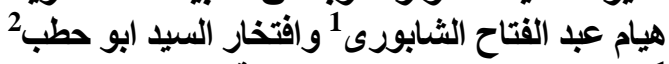

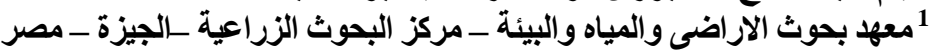

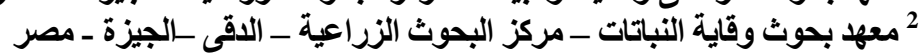

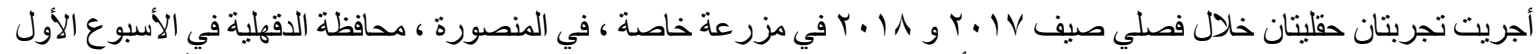

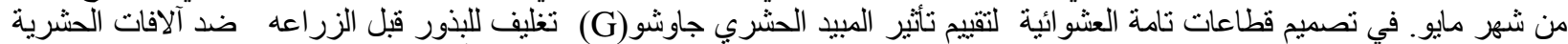

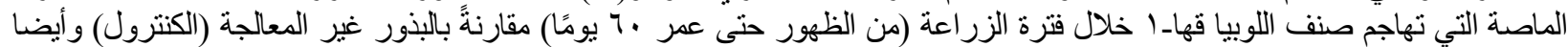

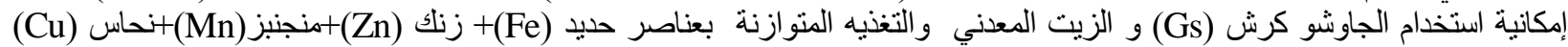

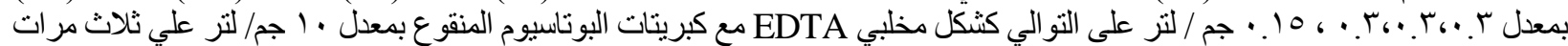

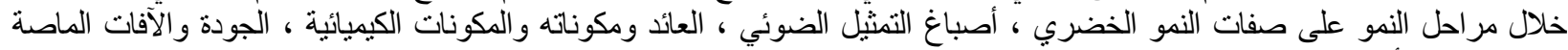

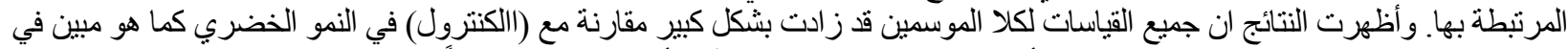

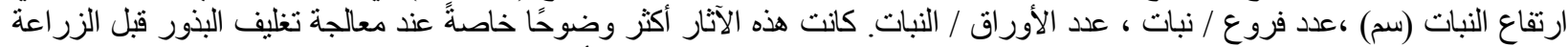

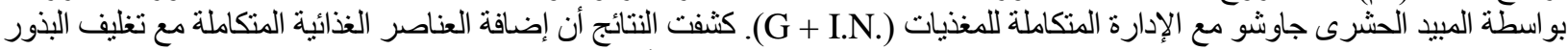

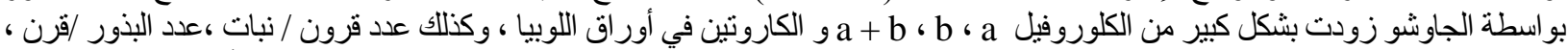

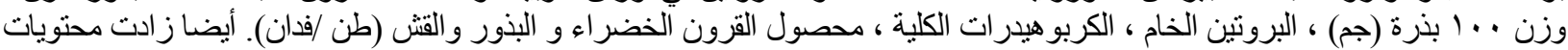

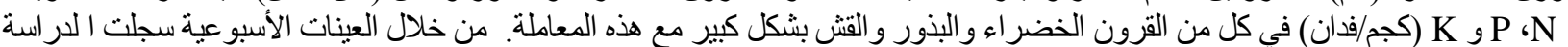

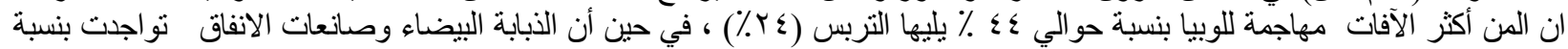

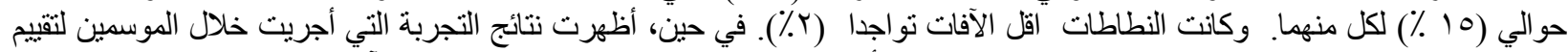

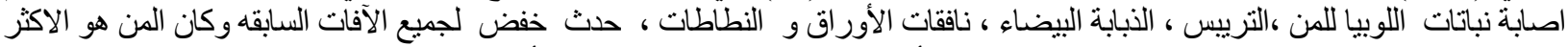

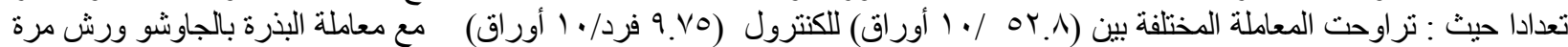

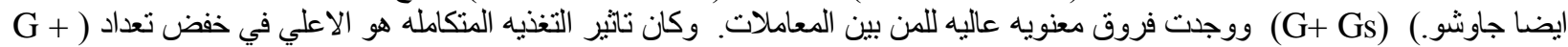
(I.N

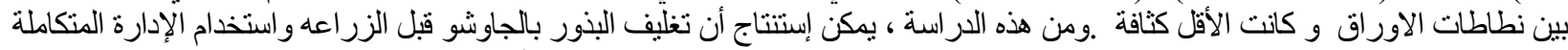

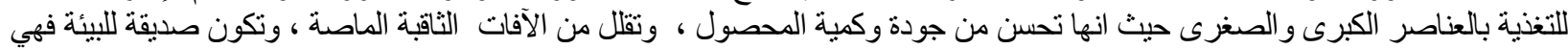
آمنة وقليلة التكاليف. و وذه المعلومات مفيدة لمز ارعي الخضروات. 